\title{
Lidia Zyblikiewicz
}

Kraków

\section{Aktywność zawodowa kobiet w Krakowie w II połowie XIX wieku}

Celem badań, których rezultaty przedstawiono poniżej, było sprawdzenie w świetle danych statystycznych, jaka była skala aktywności zawodowej kobiet mieszkających w Krakowie w drugiej połowie XIX wieku. Autorce zależało na ustaleniu, czy potwierdzi się - przynajmniej w odniesieniu do tej populacji miejskiej - dość powszechne przekonanie, że kobiety w większym zakresie podjęły pracę zarobkową dopiero w czasie I wojny światowej, a ,działalność zawodowa kobiet jeszcze w XIX wieku była nie tylko mało realna, ale również źle postrzegana"1.

Podczas analizy wykorzystano standard klasyfikacji zawodowej HISCO ( $\mathrm{Hi}$ storical International Standard Classification of Occupations, 2002²). Klasyfikacja ta przyporządkowuje aktywnych zawodowo do dziesięciu grup głównych (choć grupy 0 i 1 oraz 7, 8 i 9 zazwyczaj są łączone) podzielonych na 83 podgrupy i 284 jednostki klasyfikacyjne, a te na 1881 kategorii zawodowych ${ }^{3}$.

${ }^{1}$ Gabriela Matuszek, Kobiety a proces modernizacji-rekonesans galicyjskiej herstorii, [w:] Kraków i Galicja wobec przemian cywilizacyjnych (1866-1914). Studia i szkice, red. Krzysztof Fiołek, Marian Stala, Kraków 2011, s. 63. Gwoli sprawiedliwości należy zauważyć, że cytowane zdanie jest raczej dowodem na siłę stereotypu; w niezwykle ciekawym artykule Gabriela Matuszek pokazuje, że podjęcie pracy zawodowej przez kobiety nie było zadaniem łatwym, ale z pewnością realnym. Zob. także: Maria Nietyksza, Ludność Warszawy na przełomie XIX i XX wieku, Warszawa 1971, s. 137-213; Kobieta i praca. Wiek XIX i XX, red. Anna Żarnowska, Andrzej Szwarc, t. VI, Warszawa 2000; Radosław Poniat, Stużba domowa w miastach na ziemiach polskich od połowy XVIII do końca XIX w., Warszawa 2014.

${ }^{2}$ Marco H.D. van Leeuwen, Ineke Maas, Andrew Miles, HISCO Historical International Standard Classification of Occupations, Leuven 2002.

${ }^{3}$ Więcej na temat klasyfikacji HISCO zob. Konrad Wnęk, Własność nieruchomości w Krakowie w potowie XIX w., Kraków 2011, s. 206-214; Lidia A. Zyblikiewicz, Ludność Krakowa 
Podstawę źródłową analiz stanowią oryginalne karty spisów powszechnych z lat 1869, 1880 i 1890 zachowane w Archiwum Narodowym w Krakowie ${ }^{4}$. W oparciu o nie stworzone zostały bazy danych mieszkańców miasta dla lat 1869 i 1890 - na podstawie badania reprezentacyjnego ${ }^{5}$, dla roku 1880 - w sposób wyczerpujący ${ }^{6}$. W drugiej połowie XIX wieku przeprowadzono w Krakowie także dwa inne spisy powszechne, w 1857 roku i w 1900 roku. Nie zostały one jednak uwzględnione w czasie analizy, chociaż są dostępne w krakowskim Archiwum Narodowym ${ }^{7}$. Pierwszy (1857 rok) nie nadaje się do analizowania aktywności zawodowej (zwłaszcza kobiet) wedle dzisiejszych kryteriów, gdyż pracujących - wyłącznie mężczyzn - przyporządkowano do szesnastu grup zawodowych, a niepracujących krakowian - do jednej z dwóch grup: „mężczyźni powyżej czternastego roku życia” lub ,kobiety i dzieci płci obojga". Spis z 1900 roku natomiast nie zachował się w postaci oryginalnych kart, a tylko jako odpis sporządzony bezpośrednio po akcji spisowej. Zawiera on dane wszystkich ówczesnych mieszkańców Krakowa, tyle że bez zachowania struktury gospodarstw

w drugiej połowie XIX wieku. Struktura demograficzna, zawodowa i społeczna, Kraków 2014, s. 29-31 i 291-305.

${ }^{4}$ Archiwum Narodowe w Krakowie, zespoły: nr 86, Spis ludności miasta Krakowa z r. 1870 [błąd w tytule, spis przeprowadzono według stanu ludności 31 grudnia 1869 r. - przyp. L.A.Z.], nr 87, Spis ludności miasta Krakowa z r. 1880 i nr 88, Spis ludności miasta Krakowa z r. 1890.

${ }_{5}^{5}$ Próbę statystyczną dobrano przy założeniu dziewięćdziesięciopięcioprocentowego przedziału ufności i takiej samej mocy próby. Do ustalenia wielkości próby przyjęto konwencję Cohena rozkładu proporcji 0,55 do 0,50 , standardowo używaną w badaniach społecznych. Odchylenie może wynosić maksymalnie $2,5 \% \mathrm{w}$ zależności od rozkładu proporcji w badanej populacji, przy czym wartość taką osiąga tylko przy teoretycznej frakcji 0,50 . Do wyliczenia wielkości próby wykorzystano program SamplePower SPSS. W 1869 roku reprezentatywna próba obejmuje 1080 z 9265 gospodarstw domowych, dla których dysponujemy kwestionariuszami spisowymi, ponieważ zachowano jedynie karty gospodarstw, których głową była osoba przynależna do miasta. W przypadku tego spisu oznacza to, że możemy korzystać z danych ok. 75\% mieszkańców. Wprowadzono do bazy 5146 rekordów, każdy złożony z 26 pól. W bazie danych znalazło się 2716 kobiet i 2430 mężczyzn. W przypadku bazy danych dla ludności z 1890 roku wprowadzone zostały dane 7095 osób, w tym 3836 kobiet i 3259 mężczyzn. W przypadku tej bazy każdy rekord składa się z 33 pól.

${ }^{6}$ Baza danych ludności Krakowa z 1880 roku obejmuje 63022 rekordy, w tym 33440 kobiet i 29582 mężczyzn. Każdy rekord składa się z 30 pól. Liczba osób odnotowanych na kartach spisu jest większa niż oficjalnie podawana liczba cywilnej ludności obecnej w mieście w momencie krytycznym spisu. Częściowo może to wynikać z odnotowania na kartach spisowych - i zarazem w bazie danych - wojskowych mieszkających poza koszarami. Nie podlegali oni obowiązkowi podawania swoich danych podczas spisu powszechnego, dlatego zostali pominięci przy ustalaniu oficjalnej liczby ludności cywilnej. W bazie danych są jednak uwzględniani, gdyż najczęściej byli głowami gospodarstw domowych, mężami i ojcami; ich pominięcie zniekształciłoby rzeczywisty obraz populacji miasta.

7 Archiwum Narodowe w Krakowie, zespoły: nr 85, Spis ludności miasta Krakowa z r. 1857 i nr 89, Spis ludności miasta Krakowa z r. 1900.

${ }^{8}$ Szczegółowe omówienie spisu z 1857 roku zob. L.A. Zyblikiewicz, Ludność [3], s. 34-40. 
domowych, czyli bez więzi ekonomicznych wewnątrz poszczególnych złożonych jednostek badania, co w praktyce wyklucza możliwość pełnej analizy struktury zawodowej i społecznej.

\section{Ludność miasta}

Liczba ludności Krakowa od lat sześćdziesiątych XIX wieku wyraźnie rosła, a proces ten był tym bardziej zauważalny, że w latach czterdziestych i pięćdziesiątych tego stulecia mieliśmy do czynienia ze stagnacją, a nawet zmniejszaniem się wielkości populacji miasta (wykres 1). W 1857 roku, kiedy przeprowadzono w monarchii habsburskiej pierwszy spis powszechny, w Krakowie mieszkało tylko nieco ponad 41 tysięcy osób, czyli o 2\% mniej niż w 1842 roku i o $6,5 \%$ mniej niż w 1844 roku.

Jednak w 1869 roku, w czasie kolejnego spisu ludności, odnotowano w Krakowie już niemal 50 tysięcy mieszkańców, w ciągu dwunastu lat przybywało średnio 1,72\% rocznie. Wedle danych z kolejnego spisu (1880 rok) w następnych jedenastu latach przyrost był jeszcze szybszy - średnio 1,82\% rocznie. Tak znaczący wzrost liczby ludności nie mógł być spowodowany przyrostem naturalnym, a jedynie imigracją do miasta. Nie było to oczywiście zjawisko niezwykłe dla ośrodków metropolitalnych w owym czasie, jednak w Krakowie miało miejsce na bardzo dużą skalę, choć można znaleźć ośrodki rozwijające się jeszcze szybciej. Według danych krakowskiego Biura Statystycznego Miejskiego „,[p]rzyrost we Lwowie w czasie pomiędzy obu ostatniemi spisami [1869 roku i 1880 roku - przyp. L.A.Z.] wynosił 18,8 czyli roczny 1,71 , w Gracu 14,5 czyli roczny 1,32 , w Lincu 16,5 czyli roczny 1,5, w Opawie 16,1 czyli roczny 1,46, w Czerniowcach 31,7 czyli roczny 2,88, w Wiedniu 16 czyli roczny 1,45 "

Starając się określić, jaką część mieszkańców Krakowa w latach 1857 i 1869 stanowili imigranci, trzeba się odwołać do kryterium prawnej przynależności (swojszczyzny) $^{10}$. W przypadku kolejnych dwóch spisów można je uzupełnić o kategorię „miejsce urodzenia”, co jest rozwiązaniem nieco lepszym.

${ }^{9}$ Statystyka Miasta Krakowa 1887, z. 1, s. 30.

${ }^{10}$ Lidia A. Zyblikiewicz, Kobieta w Krakowie w 1880 r. w świetle ankiet powszechnego spisu ludności. Studium demograficzne, Kraków 1999, s. 78-80. 
Wykres 1. Liczba ludności Krakowa w latach 1840-1900 (w tys.)

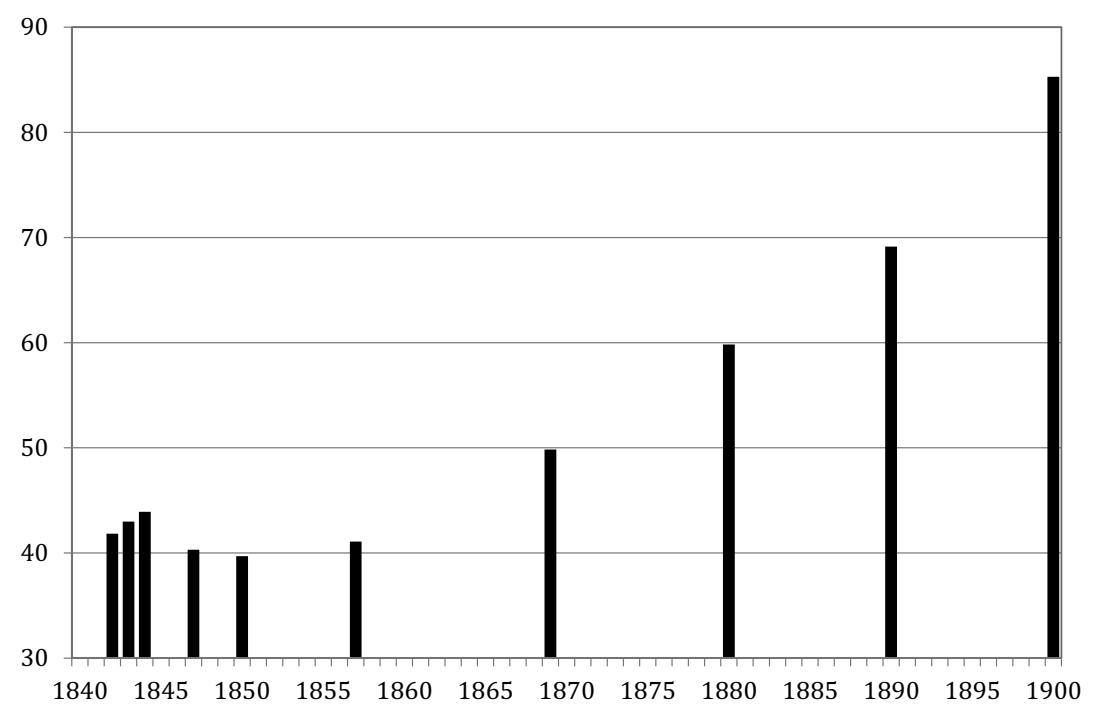

Źródło: Statystyka Miasta Krakowa 1902, z. 8, s. 3.

Biorąc pod uwagę prawo swojszczyzny, dowiadujemy się, że w 1857 roku mniej niż co piąty krakowianin pochodził spoza miasta (19\%), a dwanaście lat później imigrantem był już co czwarty (27\%). Znaczna zmiana miała jednak miejsce w latach siedemdziesiątych XIX wieku; w 1880 roku niemal połowa mieszkańców miasta ani nie miała prawa przynależności do Krakowa (45,5\%) ani też się w nim nie urodziła (48,2\%). A w 1890 roku ludność napływowa stanowiła już większość mieszkańców, przy czym właściwie nie ma znaczenia, czy bierzemy pod uwagę urodzenie (55,5\%), czy prawo swojszczyzny $(55,6 \%)$.

Ludność napływowa zmieniała strukturę wieku i płci populacji miasta, zwiększając udział kobiet oraz osób piętnastoletnich i starszych w całej populacji.

Współczynnik feminizacji w 1857 roku wynosił w Krakowie $111^{11}$ (podczas gdy w całej Galicji - 106 ${ }^{12}$ ), w 1869 roku - 112 (w całej Galicji - 103), w 1880 roku - 113 (w Galicji bez zmian) i aż 119 w 1890 roku (w całej Galicji - tylko 102).

${ }^{11}$ Współczynniki feminizacji na podstawie danych z kart spisowych ujętych w bazach danych: Spis mieszkańców Krakowa w 1857 r.; Spis mieszkańców Krakowa w 1869 r., Spis mieszkańców Krakowa w 1880 r., Spis mieszkańców Krakowa w 1890 r. Obliczenia własne.

${ }_{12}$ Współczynniki feminizacji dla całej Galicji za: Krzysztof Zamorski, Informator statystyczny do dziejów spoteczno-gospodarczych Galicji. Ludność Galicji w latach 1857-1910, KrakówWarszawa 1989, s. 45. W 1857 roku odnoszą się do ludności zamieszkałej, w latach 1869, 1880 i 1890 - do ludności obecnej. Obliczenia własne. 
Wykres 2. Piramida wieku ludności Krakowa w 1857 roku (w \%o)

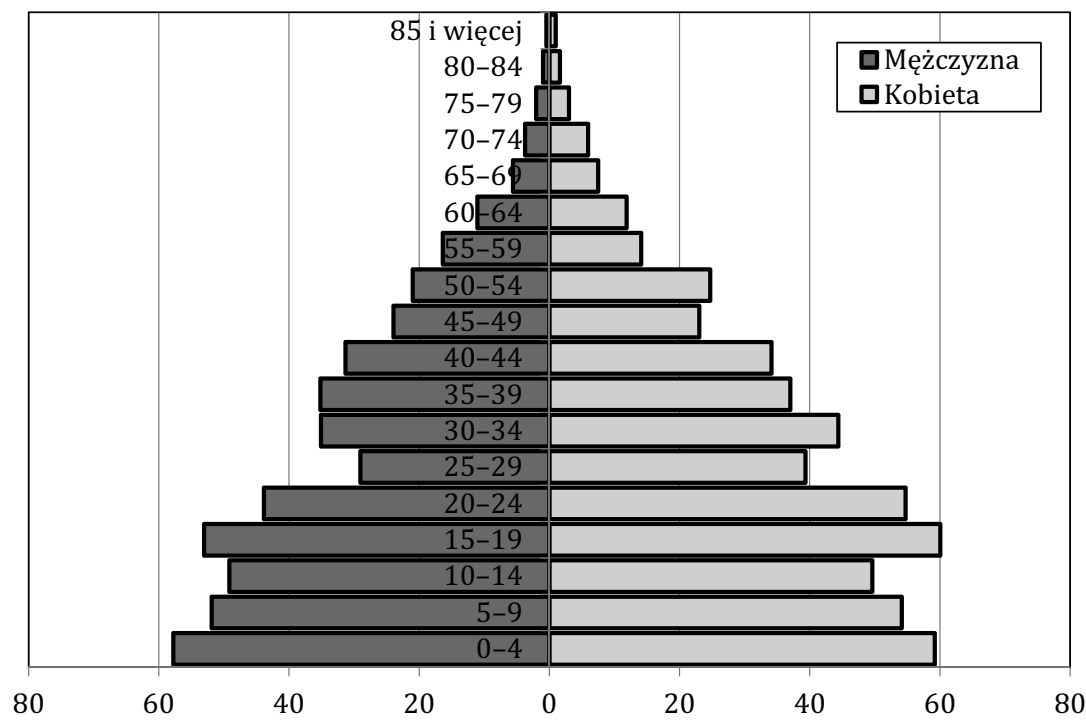

Źródło: Baza danych: Spis mieszkańców Krakowa w 1857 r. Obliczenia własne.

Przewagę liczebną kobiet w populacji miasta w 1857 roku łatwo też zauważyć na wykresie 2. Poza tym zwraca uwagę wyraźna nadreprezentacja mieszkańców płci obojga w przedziale wieku 15-19 lat, co zapewne należy wiązać z faktem, że zgodnie z § 21 austriackiego kodeksu cywilnego, z chwilą ukończenia 14. roku życia mieszkaniec monarchii habsburskiej stawał się małoletnim, a to dawało mu m.in. prawo do samodzielnego zawierania umowy o pracę ${ }^{13}$. $Z$ prawa tego jednak - sądząc z wartości widocznych na wykresie - chętniej korzystały kobiety; w przedziale wieku 15-19 lat współczynnik feminizacji wynosił 113, w kolejnym - 125, by w przedziale 25-29 lat osiągnąć wartość 136. Tak wysoki udział kobiet w rocznikach „młodych dorosłych” można bez większego ryzyka błędu interpretować jako efekt głównie kobiecej imigracji zarobkowej do Krakowa.

${ }^{13}$ Więcej na ten temat zob. Lidia A. Zyblikiewicz, Dziecko w rodzinie krakowskiej w drugiej połowie XIX wieku. Studium demograficzne, „Zeszyty Naukowe UJ. Prace Historyczne” 2008 (z. 135), s. 131. 
Wykres 3. Piramida wieku ludności Krakowa w 1869 roku (w \%o)

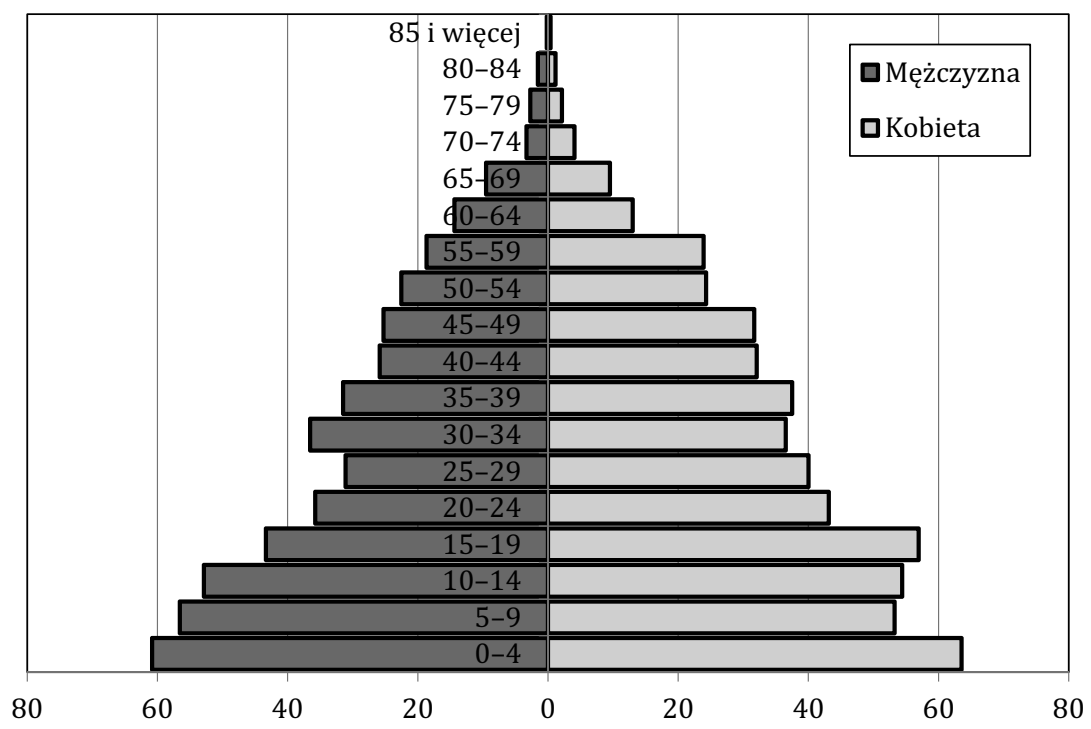

Źródło: Baza danych: Spis mieszkańców Krakowa w 1869 r. Obliczenia własne.

Piramida wieku ludności miasta w 1869 roku (wykres 3) nie różni się zasadniczo od poprzedniej, chociaż w tym przypadku wydają się być nadreprezentowane przede wszystkim kobiety w przedziale wieku 15-19 lat; współczynnik feminizacji w tej grupie wiekowej wynosi 131.

Struktura wieku i płci mieszkańców Krakowa w 1880 roku przedstawiona jako piramida wieku (wykres 4) pozwala dostrzec zmiany, jakie zachodziły w populacji miasta w latach siedemdziesiątych XIX wieku. Nadreprezentowane są przede wszystkim osoby w wieku 15-19 i 20-24 lata. We wszystkich grupach wiekowych powyżej 15 lat liczba kobiet jest wyższa - w niektórych bardzo znacznie - od liczby mężczyzn. 
Wykres 4. Piramida wieku ludności Krakowa w 1880 roku (w \%o)

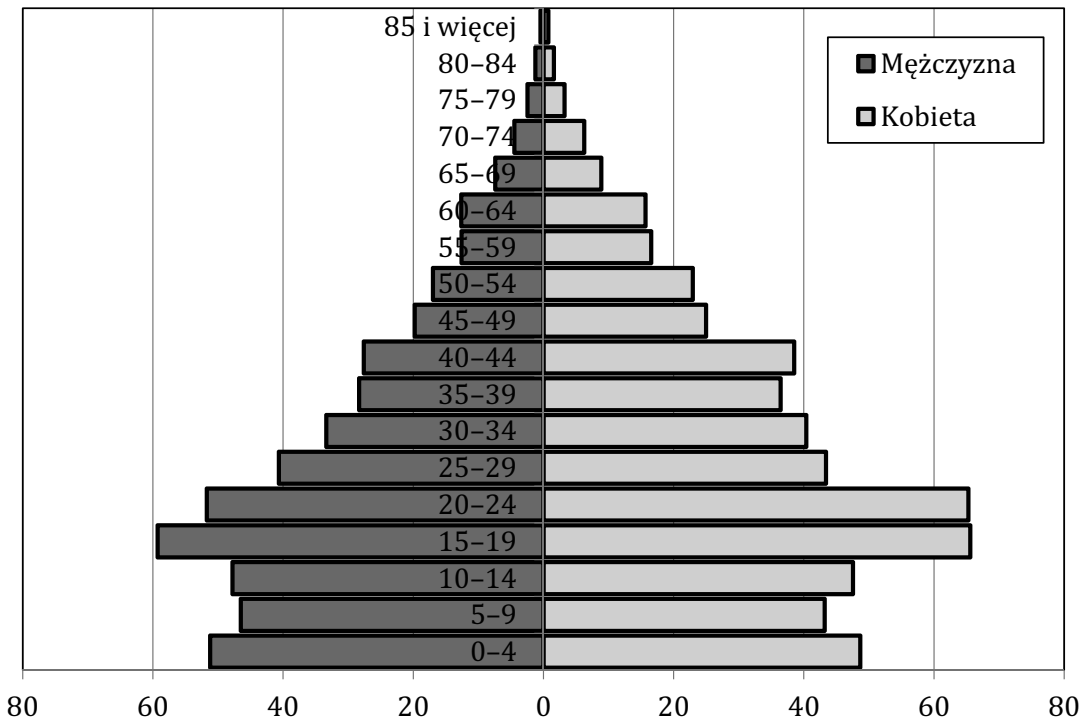

Źródło: Baza danych: Spis mieszkańców Krakowa w 1880 r. Obliczenia własne.

Bardzo podobną strukturę wieku i płci możemy zaobserwować w przypadku populacji miasta z 1890 roku (wykres 5). Różnicę widzimy w odniesieniu do osób w wieku 15-19 lat - w roku poprzedniego spisu wyraźnie więcej było w tej grupie kobiet niż mężczyzn (współczynnik feminizacji 111), w 1890 roku - odwrotnie, mężczyzn jest nieco więcej (współczynnik feminizacji 96). We wszystkich starszych rocznikach natomiast przewaga liczebna kobiet jest wyraźna, w niektórych przedziałach wiekowych (np. 60-64 lata) współczynnik feminizacji wynosi 202.

Sytuację tę tak interpretowali współcześni: „Powodem przewagi kobiet w ludności miast jest napływ ludności żeńskiej do służby i innych zarobków łatwiejszych w mieście jak na wsi dla kobiety. W innych większych miastach bywa zarazem znaczny napływ ludności męskiej do zawodów przemysłowych. W Krakowie przy małem rozwinięciu przemysłu, napływ z tego powodu ludności męskiej nie jest zbyt silny, mimo więc, że zakłady naukowe wywierają tu większą siłę atrakcyjną na ludność męską, zawsze jednak nie może to dostatecznie przeciwważyć napływowi kobiet. W starszym wieku jest znowu znaczna przewaga kobiet sędziwych, na co prawdopodobnie wpływa osiedlanie się tu starszych kobiet na emeryturę i dewocyę"14.

${ }^{14}$ Statystyka Miasta Krakowa 1887, z. 1, s. 56. 
Wykres 5. Piramida wieku ludności Krakowa w 1890 roku (w \%o)

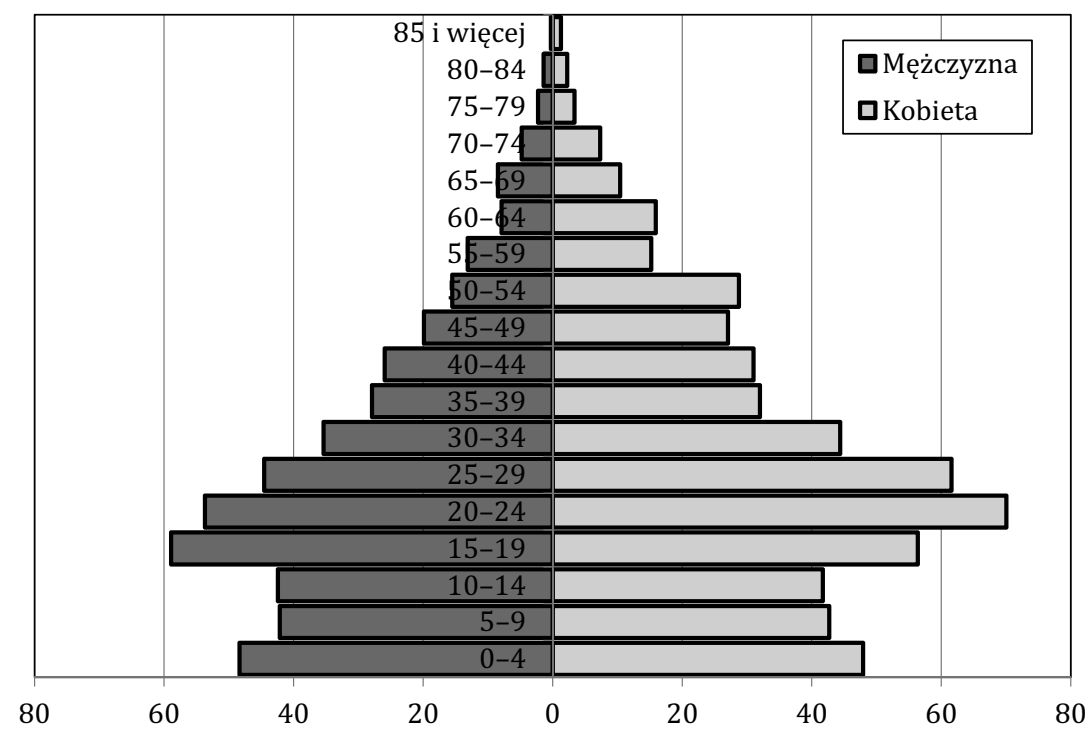

Źródło: Baza danych: Spis mieszkańców Krakowa w 1890 r. Obliczenia własne.

\section{Skala aktywności zawodowej kobiet}

Aktywność zawodowa krakowian bardzo wyraźnie rosła w drugiej połowie XIX wieku. Udział pracujących zarobkowo w 1869 roku w całej populacji miasta sięgał niespełna jednej trzeciej, w 1890 roku wynosił już blisko połowę wszystkich mieszkających w mieście (tabela 1).

Tabela 1. Aktywność zawodowa krakowian w latach 1869, 1880 i 1890 (w \%)

\begin{tabular}{lccccccccc}
\hline \multirow{2}{*}{$\begin{array}{c}\text { Aktywność } \\
\text { zawodowa }\end{array}$} & \multicolumn{3}{c}{ Mężczyźni } & \multicolumn{3}{c}{ Kobiety } & \multicolumn{3}{c}{ Razem } \\
\cline { 2 - 10 } & 1869 & 1880 & 1890 & 1869 & 1880 & 1890 & 1869 & 1880 & 1890 \\
\hline Aktywni & 49,3 & 58,0 & 61,5 & 16,5 & 34,0 & 38,6 & 32,0 & 45,3 & 49,1 \\
Nieaktywni & 50,7 & 42,0 & 38,5 & 83,5 & 66,0 & 61,4 & 68,0 & 54,7 & 50,9 \\
Razem & 100,0 & 100,0 & 100,0 & 100,0 & 100,0 & 100,0 & 100,0 & 100,0 & 100,0 \\
\hline
\end{tabular}

Źródło: Bazy danych: Spis mieszkańców Krakowa w 1869 r., Spis mieszkańców Krakowa w 1880 r. i Spis mieszkańców Krakowa w 1890 r. Obliczenia własne. 
Jeszcze wyraźniej rósł udział aktywnych zawodowo kobiet wśród mieszkanek Krakowa. W 1869 roku (wykres 6) pracowała co szósta krakowianka, jedenaście lat później już do trzecia (wykres 7), a po kolejnych dziesięciu latach - blisko $40 \%$ (wykres 8 ).

Wykres 6. Aktywność zawodowa kobiet w 1869 roku (w \%)

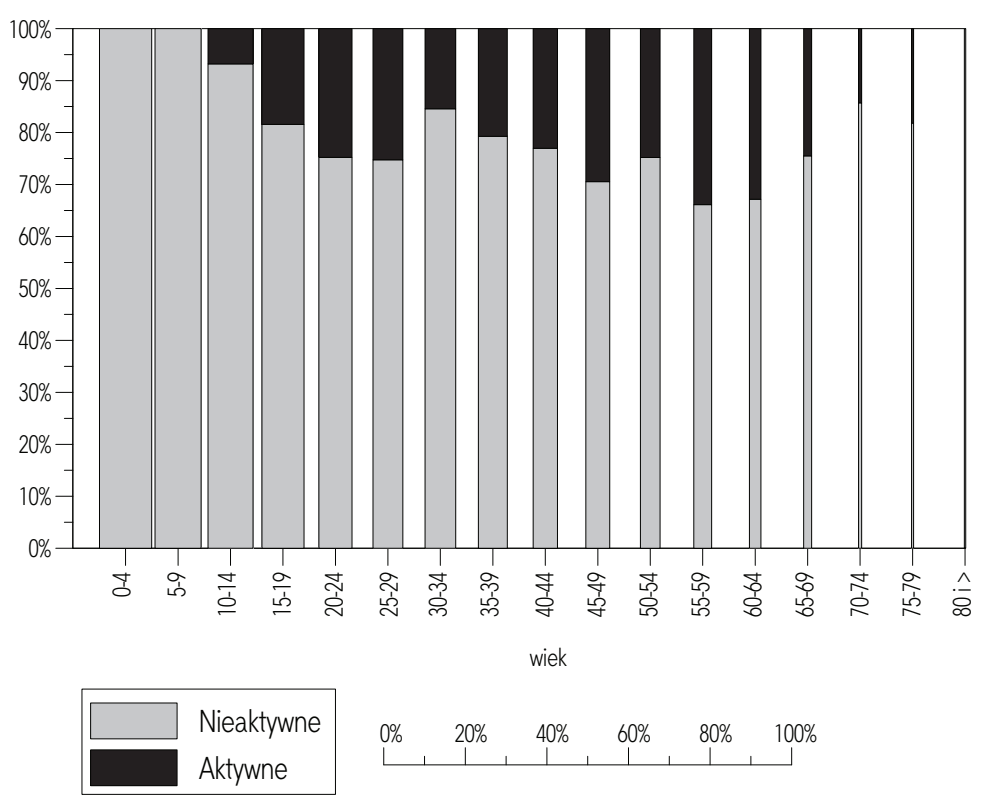

Źródło: Baza danych: Spis mieszkańców Krakowa w 1869 r. Obliczenia własne.

W 1869 roku pracowało aż 6,8\% kobiet najmłodszych, w przedziale wieku 10-14 lat, które nie mogły jeszcze zgodnie z prawem samodzielnie podejmować pracy i były objęte obowiązkiem szkolnym. W kolejnych przedziałach wiekowych pracowała co piąta krakowianka, między 45. a 64. rokiem życia - co trzecia. W przedziale wiekowym 65-69 lat pracowała wciąż co czwarta, a między 70 . a 74. rokiem życia - co szósta mieszkanka miasta. Dopiero wśród pań osiemdziesięcioletnich i starszych nie pracowała żadna. 
Wykres 7. Aktywność zawodowa kobiet w 1880 roku (w \%)

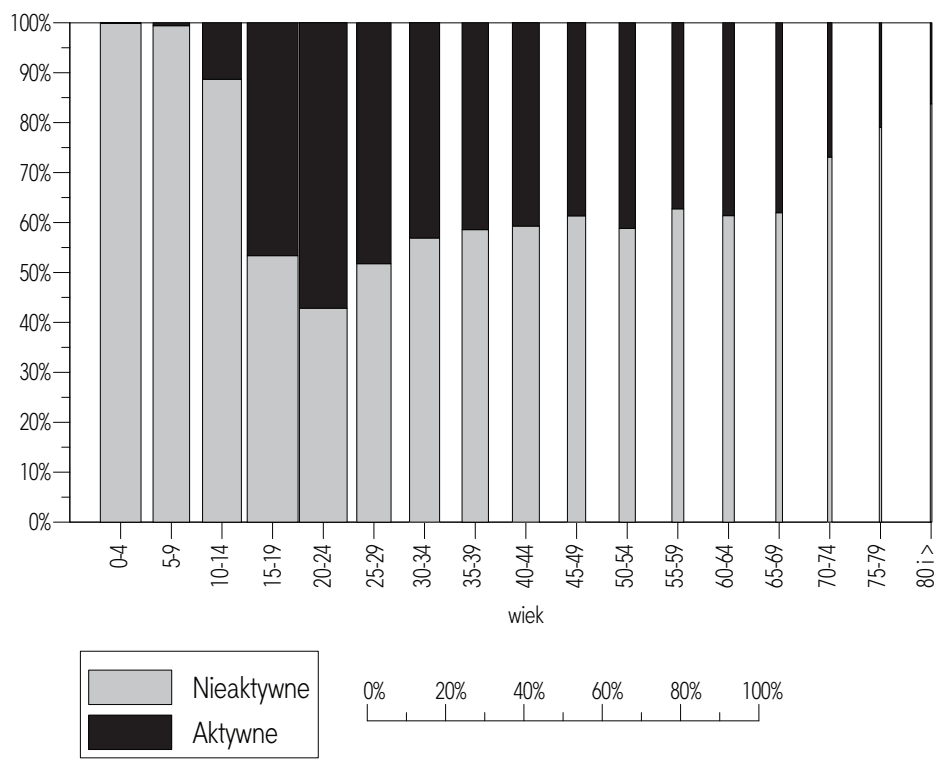

Źródło: Baza danych: Spis mieszkańców Krakowa w 1880 r. Obliczenia własne.

W latach siedemdziesiątych XIX wieku udział aktywnych zawodowo kobiet w subpopulacji krakowianek wzrósł ponad dwukrotnie - z 16,5\% w 1869 roku do 34\% w 1880 roku (wykres 7). Pracowały nawet - na szczęście bardzo nieliczne - dziewczynki poniżej 10. roku życia. Między 10. a 14. urodzinami aktywność zawodową wykazywała już co dziesiąta krakowianka. W przedziale 15-19 lat pracowała prawie do druga, w kolejnym - aż 57\%. Niemal połowa kobiet między 25 a 29 lat była aktywna zawodowo, w wszystkich przedziałach od 30-34 lat do 65-69 lat - ok. 40\%. W wieku 70-74 lat pracowała co czwarta krakowianka, w przedziale wiekowym 75-79 lat - co piąta, a nawet wśród kobiet 80-letnich i starszych - co szósta. 
Wykres 8. Aktywność zawodowa kobiet w 1890 roku (w \%)

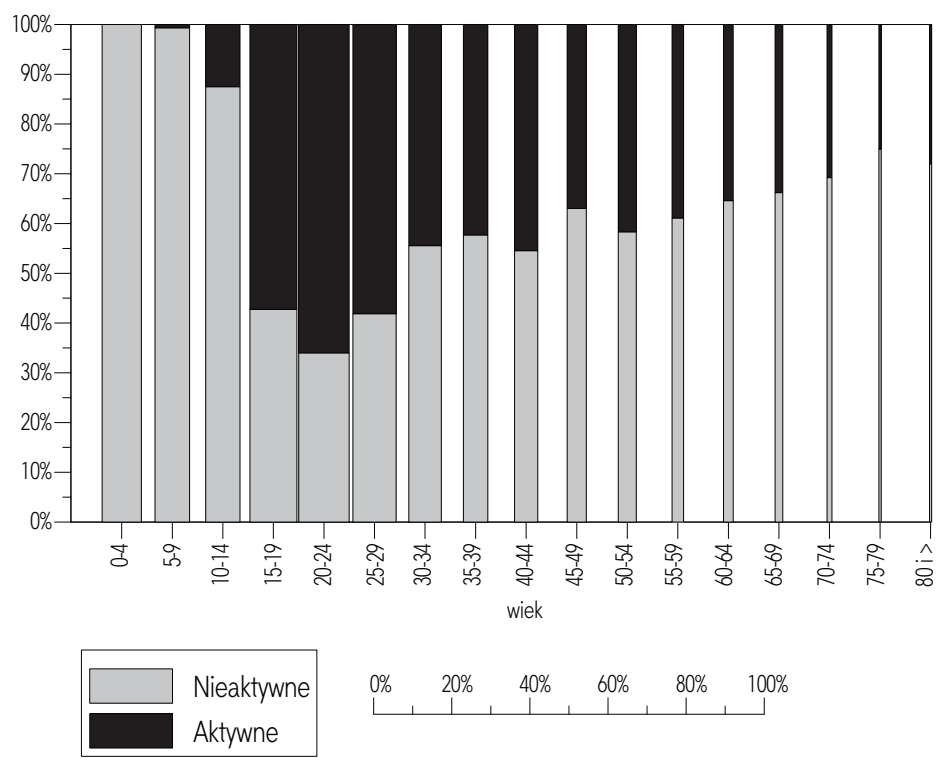

Źródło: Baza danych: Spis mieszkańców Krakowa w 1890 r. Obliczenia własne.

W 1890 roku 38,6\% kobiet mieszkających w Krakowie było aktywnych zawodowo. We wszystkich niemal przedziałach wiekowych, z wyjątkiem dwóch pierwszych, udział pracujących był wyższy niż w roku poprzedniego spisu. W przedziale wieku 15-19, 20-24 i 25-29 lat pracowało niemal dwie trzecie krakowianek, a nawet wśród najstarszych, powyżej 80 lat, aktywna zarobkowo pozostawała ponad jedna czwarta.

\section{Aktywność zawodowa kobiet według wyznań}

Populacja Krakowa była niejednolita; w mieście funkcjonowały dwie zupełnie różne społeczności - rzymskich katolików i żydów (tabela 2). Przy czym udział rzymskich katolików stopniowo wzrastał z 55,8\% w 1869 roku do 67,5\% w 1890 roku, a żydów spadał z 43,5\% do 30,5\%. Udział przedstawicieli innych wyznań był niewielki - w badanym okresie nie przekraczał $2 \%$. 
Tabela 2. Struktura wyznaniowa ludności Krakowa w latach 1869, 1880 i 1890 (w \%)

\begin{tabular}{ccccc}
\hline \multirow{2}{*}{ Rok } & \multicolumn{3}{c}{ Wyznanie } & \multirow{2}{*}{ Razem } \\
\cline { 2 - 4 } & rzymskokatolickie & mojżeszowe & inne* & \\
\hline 1869 & 55,8 & 43,5 & 0,7 & 100,0 \\
1880 & 65,5 & 32,9 & 1,7 & 100,0 \\
1890 & 67,5 & 30,5 & 2,0 & 100,0 \\
\hline
\end{tabular}

* W grupie „inne” znajdują się wyznania: greckokatolickie, ewangelicko-augsburskie, ewangelicko-helweckie, anglikańskie, protestanckie, ormiańskokatolickie i prawosławne, a także kategorie „bez wyznania” i ,nieznane”.

Źródło: Bazy danych: Spis mieszkańców Krakowa w 1869 r., Spis mieszkańców Krakowa w 1880 r. i Spis mieszkańców Krakowa w 1890 r. Obliczenia własne.

Jak bardzo różniły się między sobą dwie największe grupy wyznaniowe, możemy stwierdzić, gdy spojrzymy na skalę aktywności zawodowej kobiet w 1869 roku pracowało 43\% rzymskich katoliczek i tylko 8\% żydówek, w roku kolejnego spisu - 42\% katoliczek i 18\% żydówek, a 1890 roku odpowiednio $44 \%$ i $27 \%$. W całym badanym okresie udział aktywnych zawodowo wśród rzymskich katoliczek utrzymywał się na podobnym poziomie, natomiast pracujących żydówek - bardzo szybko rósł.

Trzeba przy tym pamiętać, że w 1869 roku chodzi tylko o te kobiety, które zostały odnotowane podczas spisu jako wykonujące określoną pracę zarobkową. Instrukcja obowiązująca podczas tego spisu sprawiała, że te kobiety, które pracowały, pomagając ojcu czy mężowi w prowadzeniu warsztatu lub kramu, ale nie zadeklarowały żadnego własnego źródła dochodów, niekoniecznie zostawały odnotowane jako aktywne zawodowo. „W r. 1869 wszystkie osoby należące do rodziny i mające zajęcie w rodzinie, liczono jako osoby bez oznaczonego zajęcia i rozróżniano pomiędzy niemi jedynie osoby w wieku poniżej i powyżej lat 14 . W r. zaś 1880 nakazano przy każdym rodzaju zajęcia, odróżniać osoby działające samodzielnie, pomocników, robotników pracujących w zawodzie, oraz członków rodziny i służby"15. Jednak ,w obu kartach spisowych z r. 1869 i z r. 1880 znajdują się po dwie rubryki zbliżone do siebie, z których jedna ma na celu oznaczenie zajęcia, a druga oznaczenie bliższego stosunku pracy, ale dalsze zestawienia są przy obu spisach zupełnie odmienne"16. Teoretycznie zatem materiał źródłowy na kartach spisowych jest w pełni porównywalny, a różnice widoczne dopiero w oficjalnie publikowanych wynikach spisów, trzeba jednak wziąć pod uwagę,

\footnotetext{
${ }_{15}$ Statystyka Miasta Krakowa 1887, z. 1, s. 93.

16 Tamże.
} 
że założone programy spisowe mogły nieco odmiennie wpływać na sposób rejestrowania informacji.

Większość pracujących zarobkowo rzymskich katoliczek była stanu wolnego; w 1869 roku - ponad połowa (53\%), w latach kolejnych spisów odpowiednio $61 \%$ i 62\% (wykres 9). Jednak znaczący udział miały także pracujące mężatki; w 1869 roku co trzecia pracująca katoliczka była zamężna, w 1880 roku i 1890 roku - co czwarta. Zamążpójście nie oznaczało bynajmniej rezygnacji z aktywności zawodowej, choć widać, że udział mężatek zmniejszał się stopniowo, wzrastał natomiast odsetek panien. We wszystkich badanych latach więcej niż co dziesiąta pracująca krakowianka tego wyznania była wdową.

Wykres 9. Struktura subpopulacji kobiet wyznania rzymskokatolickiego według stanu cywilnego w latach 1869, 1880 i 1890 (w \%)

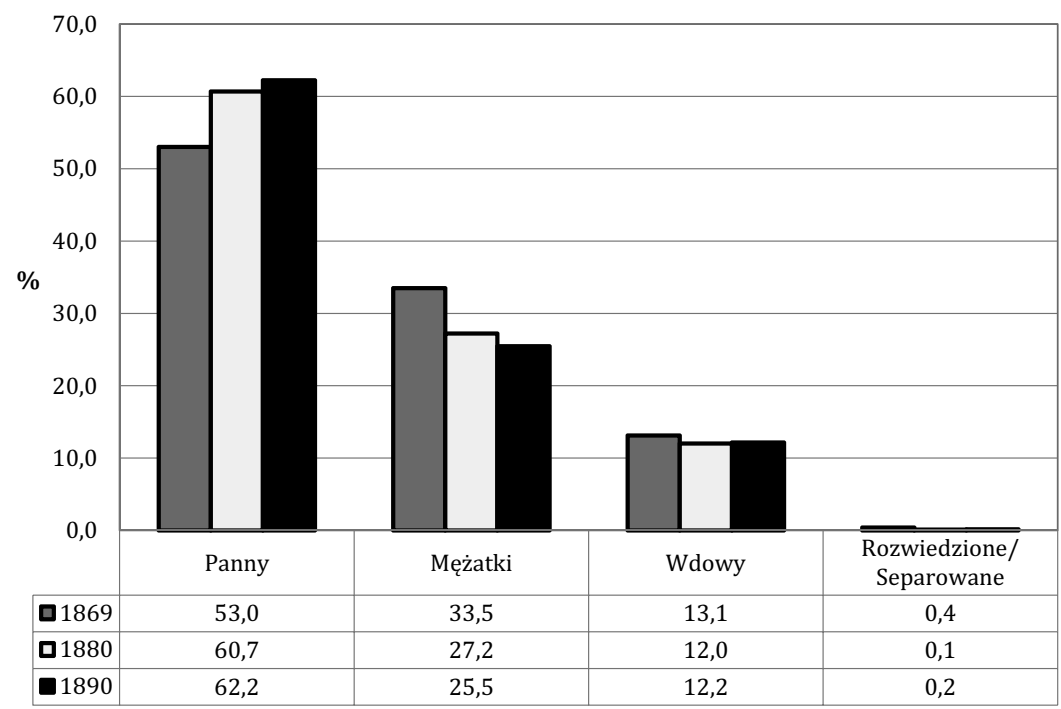

Źródło: Bazy danych: Spis mieszkańców Krakowa w 1869 r., Spis mieszkańców Krakowa w 1880 r. i Spis mieszkańców Krakowa w 1890 r. Obliczenia własne.

Panny stanowiły większość aktywnych zawodowo kobiet także wśród wyznawczyń judaizmu; w 1869 roku - 57\%, w 1880 roku-59\%, w 1890 roku-56\%, ich udział nie zmieniał się więc znacząco w badanym okresie (wykres 10). W niewielkim stopniu wśród pracujących żydówek zmieniał się także udział mężatek - 35\% w 1869 roku, 33\% w 1880 roku i 35\% w 1890 roku oraz wdów - odpowiednio: $8 \%, 8 \%$ i $9 \%$. 
Wykres 10. Struktura subpopulacji kobiet wyznania mojżeszowego według stanu cywilnego w latach 1869, 1880 i 1890 (w \%)

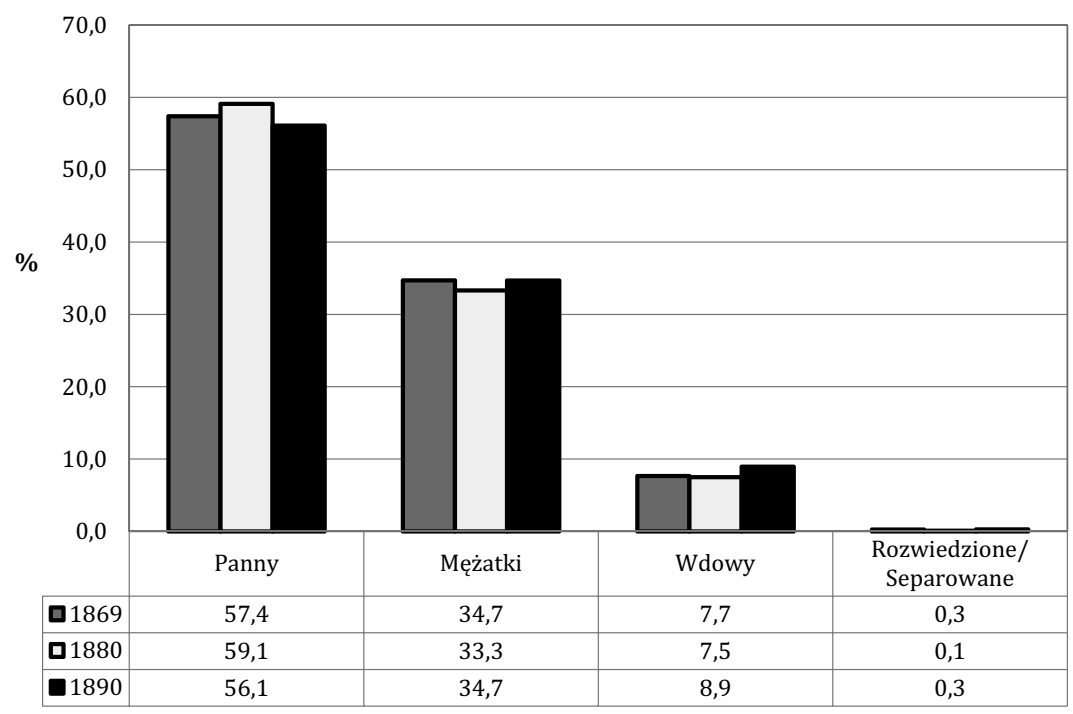

Źródło: Bazy danych: Spis mieszkańców Krakowa w 1869 r., Spis mieszkańców Krakowa w 1880 r. i Spis mieszkańców Krakowa w 1890 r. Obliczenia własne.

W całej subpopulacji krakowianek rzymskich katoliczek największy (i rosnący w kolejnych badanych latach) odsetek osób aktywnych zawodowo był wśród kobiet stanu wolnego (tabela 3); w 1869 roku pracowała niemal co czwarta panna (23\%), w latach kolejnych - co trzecia (31\% w 1880 roku i 33\% w 1890 roku). Trzeba przy tym pamiętać, że w 1869 roku 37\% rzymskokatolickich panien w Krakowie miało od 0 do 9 lat, w 1880 roku $-23 \%$, w 1890 roku -24\%, a choćby $\mathrm{z}$ racji wieku były one w ogromnej większości bierne zawodowo. Zastrzeżenie to nie dotyczy mężatek tego wyznania, wśród których w 1869 roku pracowało niespełna 7\%, a w latach kolejnych spisów - nieco ponad 5\%. Wśród wdów odsetek aktywnych zawodowo był w 1869 roku niemal dwa razy wyższy niż wśród mężatek - $13 \%$, w kolejnych dwóch latach spisowych obniżył się do poziomu zbliżonego do kobiet zamężnych $-6 \%$.

Zmieniała się też w badanych latach struktura subpopulacji rzymskich katoliczek według stanu cywilnego. Kobiety stanu wolnego stanowiły w 1869 roku 53\% wszystkich krakowianek tego wyznania, w 1880 roku $-61 \%$, a w 1890 roku - już 62\%. Równocześnie spadał odsetek mężatek, których w 1869 roku było $34 \%$, a w latach kolejnych spisów odpowiednio $27 \%$ i $26 \%$. Niezmienny natomiast pozostawał udział wdów, odpowiednio $13 \%, 12 \%$ i $12 \%$. Coraz większy 
odsetek panien i ich rosnąca aktywność zawodowa sprawiły, że w całej subpopulacji mieszkających w Krakowie rzymskich katoliczek udział kobiet zarabiających samodzielnie na swoje utrzymanie był zaskakująco wysoki i we wszystkich badanych latach wyraźnie przekraczał dwie piąte: $43 \%$ w 1869 roku, 42\% w 1880 roku i 44\% w 1890 roku.

Tabela 3. Udział aktywnych i biernych zawodowo w populacji rzymskich katoliczek w poszczególnych grupach stanu cywilnego w Krakowie w latach 1869, 1880 i 1890 (w \%)

\begin{tabular}{|c|c|c|c|c|c|c|c|c|c|}
\hline \multirow[b]{2}{*}{ Stan cywilny } & \multicolumn{3}{|c|}{1869} & \multicolumn{3}{|c|}{1880} & \multicolumn{3}{|c|}{1890} \\
\hline & 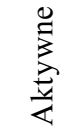 & 苛 & $\stackrel{\mathscr{g}}{\Xi}$ & 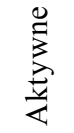 & 苛 & 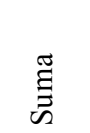 & $\overbrace{\frac{\pi}{4}}$ & $\underset{\mathscr{D}}{0}$ & $\stackrel{\widetilde{g}}{\Xi}$ \\
\hline Panna & 22,7 & 77,3 & 100,0 & 30,5 & 69,5 & 100,0 & 33,0 & 67,0 & 100,0 \\
\hline Mężatka & 6,7 & 93,3 & 100,0 & 5,3 & 94,7 & 100,0 & 5,2 & 94,8 & 100,0 \\
\hline Wdowa & 13,0 & 87,0 & 100,0 & 6,0 & 94,0 & 100,0 & 5,5 & 94,5 & 100,0 \\
\hline $\begin{array}{l}\text { Rozwiedziona/ } \\
\text { Separowana }\end{array}$ & 0,5 & 99,5 & 100,0 & 0,1 & 99,9 & 100,0 & 0,1 & 99,9 & 100,0 \\
\hline Nieznany & 0,0 & 100,0 & 100,0 & 0,0 & 100,0 & 100,0 & 0,1 & 99,9 & 100,0 \\
\hline Ogółem & 42,9 & 57,1 & 100,0 & 41,9 & 58,1 & 100,0 & 43,8 & 56,2 & 100,0 \\
\hline
\end{tabular}

Źródło: Bazy danych: Spis mieszkańców Krakowa w 1869 r., Spis mieszkańców Krakowa w 1880 r. i Spis mieszkańców Krakowa w 1890 r. Obliczenia własne.

Mieszkające w Krakowie żydówki w 1869 roku stanu wolnego stanowiły ponad 57\% wszystkich kobiet tego wyznania, a odsetek czynnych zawodowo panien wynosił tylko 3\%. Jednak już w roku następnego spisu panny stanowiły 59\% wszystkich wyznawczyń judaizmu, a co dziesiąta z nich pracowała. W 1890 roku udział kobiet stanu wolnego obniżył się do 56\%, natomiast udział aktywnych zawodowo wśród panien wzrósł do blisko $14 \%$.

Mężatką w badanych latach była co trzecia żydówka (odpowiednio 35\%, $33 \%, 35 \%$ wszystkich kobiet tego wyznania), ale ich aktywność zawodowa rosła bardzo wyraźnie: w 1869 roku pracowała jedna na sto czterdzieści, 1880 roku co trzydziesta, a dziesięć lat później - co dwunasta. Wdowy stanowiły w latach dwóch pierwszych analizowanych spisów 8\% wyznawczyń judaizmu, w 1890 roku - niespełna 9\%. Wśród nich aktywnych zawodowo było 4\% w latach 1869 i 1880 oraz prawie $5 \% \mathrm{w} 1890$ roku.

W całej subpopulacji żydówek w 1869 roku pracowała co dwunasta, w 1880 roku prawie co piąta, a po kolejnych dziesięciu latach - więcej niż co czwarta. 
Tabela 4. Udział aktywnych i biernych zawodowo w populacji żydówek w poszczególnych grupach stanu cywilnego w Krakowie w latach 1869, 1880 i $1890(\mathrm{w} \%)$

\begin{tabular}{|c|c|c|c|c|c|c|c|c|c|}
\hline \multirow[b]{2}{*}{ Stan cywilny } & \multicolumn{3}{|c|}{1869} & \multicolumn{3}{|c|}{1880} & \multicolumn{3}{|c|}{1890} \\
\hline & 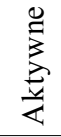 & $\stackrel{\mathscr{E}}{\stackrel{ \pm}{0}}$ & $\begin{array}{c}\stackrel{\Xi}{\Xi} \\
\mathscr{\Xi}\end{array}$ & 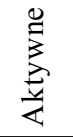 & $\frac{\mathscr{E}}{\stackrel{\Xi}{0}}$ & $\begin{array}{c}\stackrel{\Xi}{\Xi} \\
\text { ڤ }\end{array}$ & 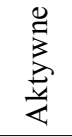 & 苛 & $\begin{array}{l}\underset{\Xi}{\Xi} \\
\stackrel{\Xi}{\Xi}\end{array}$ \\
\hline Panna & 3,0 & 97,0 & 100,0 & 10,2 & 89,8 & 100,0 & 13,6 & 86,4 & 100,0 \\
\hline Mężatka & 0,7 & 99,3 & 100,0 & 3,4 & 96,6 & 100,0 & 8,1 & 91,9 & 100,0 \\
\hline Wdowa & 4,1 & 95,9 & 100,0 & 4,2 & 95,8 & 100,0 & 4,9 & 95,1 & 100,0 \\
\hline $\begin{array}{l}\text { Rozwiedziona/ } \\
\text { Separowana }\end{array}$ & 0,1 & 99,9 & 100,0 & 0,5 & 99,5 & 100,0 & 0,3 & 99,7 & 100,0 \\
\hline Nieznany & 0,2 & 99,8 & 100,0 & 0,0 & 100,0 & 100,0 & 0,1 & 99,9 & 100,0 \\
\hline Razem & 8,1 & 91,9 & 100,0 & 18,3 & 81,7 & 100,0 & 26,9 & 73,1 & 100,0 \\
\hline
\end{tabular}

Źródło: Bazy danych: Spis mieszkańców Krakowa w 1869 r., Spis mieszkańców Krakowa w 1880 r. i Spis mieszkańców Krakowa w 1890 r. Obliczenia własne.

\section{Zawody wykonywane przez krakowianki}

Ponad połowa (51\%) aktywnych zawodowo mieszkanek miasta w 1869 roku wykonywała zawód z grupy piątej według klasyfikacji HISCO (pracownicy usług), a ich odsetek w kolejnych latach był coraz większy - 58\% w 1880 roku i $59 \%$ w 1890 roku (tabela 5).

Największy udział w gronie aktywnych zawodowo kobiet pracujących w grupie piątej miały służące do posług domowych (5-40.10). W 1869 roku stanowiły one $65 \%$ pracujących w usługach, w 1880 roku ich udział zmniejszył się do $60 \%$, a w 1890 roku - do 54\%. Następną znaczącą grupę stanowiły kucharki w gospodarstwach prywatnych (5-31.40), ich odsetek w kolejnych latach spisowych wynosił 14\%, 18\% i 19\%. W 1869 roku stosunkowo liczną grupę tworzyły właścicielki i współwłaścicielki drobnych szynków i kawiarni (5-10.50 - pracujący właściciel kawiarni, baru lub baru przekąskowego) - 13\%, ich udział w kolejnych badanych latach spadł jednak do 1\%. W latach 1869 i 1880 6\% pracownic usług było praczkami (5-60.10), w 1890 roku - już tylko 3\%. Coraz mniejszy był także udział pokojówek prywatnych (5-40.30) - w 1869 roku 3\%, w 1880 roku i 1890 roku $2 \%$, rósł natomiast odsetek pokojówek hotelowych (5-40.50), odpowiednio $3 \%, 4 \%$ i $8 \%$. Coraz większa część usługodawczyń zajmowała się opieką nad dziećmi (5-40.35), w 1869 roku 1\%, w 1880 roku 2\%, w 1880 roku 3\%. Wśród pozostałych pracownic usług, z udziałem poniżej $1 \%$, odnotowano jeszcze: kelnerki (5-32.10), właścicielki restauracji (5-10.30) i pensjonatów (5-10.40), kucharki pracujące poza gospodarstwami prywatnymi (5-31.30), panny do towarzystwa 
(5-40.40), fryzjerki (5-70.25), a nawet prostytutki (5-99.80). W ramach ciekawostki można dodać, że w 1880 roku dwie krakowianki wykonywały zawód prywatnego detektywa (5-89.20).

Tabela 5. Struktura zawodowa kobiet w Krakowie w latach 1869, 1880 i 1890 według głównych grup HISCO (w \%)

\begin{tabular}{|c|c|c|c|c|c|}
\hline \multicolumn{3}{|c|}{ Grupy główne HISCO } & \multicolumn{3}{|c|}{ Rok } \\
\hline Kod & Nazwa w języku angielskim & Tłumaczenie na język polski & 1869 & 1880 & 1890 \\
\hline $0 / 1$ & $\begin{array}{l}\text { Professional, technical and } \\
\text { related workers }\end{array}$ & $\begin{array}{l}\text { Wolne zawody i inni wysoko } \\
\text { wykwalifikowani }\end{array}$ & 4,2 & 10,2 & 5,3 \\
\hline 2 & $\begin{array}{l}\text { Administrative and managerial } \\
\text { workers }\end{array}$ & $\begin{array}{l}\text { Pracownicy administracyjni } \\
\text { i zarządzający }\end{array}$ & 0,7 & 0,7 & 1,1 \\
\hline 3 & Clerical and related workers & Urzędnicy i tym podobni & 0,9 & 0,3 & 0,3 \\
\hline 4 & Sales workers & Pracownicy handlu & 8,9 & 6,4 & 11,1 \\
\hline 5 & Service workers & Pracownicy usług & 50,7 & 58,0 & 58,6 \\
\hline 6 & $\begin{array}{l}\text { Agricultural, animal, husbandry } \\
\text { and forestry workers, fishermen } \\
\text { and hunters }\end{array}$ & $\begin{array}{l}\text { Rolnicy, hodowcy, leśnicy, } \\
\text { rybacy i myśliwi }\end{array}$ & 0,4 & 0,1 & 0,1 \\
\hline $7 / 8 / 9$ & $\begin{array}{l}\text { Production and related workers, } \\
\text { transport equipment operators } \\
\text { and labourers }\end{array}$ & $\begin{array}{l}\text { Pracownicy związani z pro- } \\
\text { dukcją i transportem oraz } \\
\text { robotnicy }\end{array}$ & 34,2 & 24,3 & 23,6 \\
\hline Razem & & & 100,0 & 100,0 & 100,0 \\
\hline
\end{tabular}

Źródło: Bazy danych: Spis mieszkańców Krakowa w 1869 r., Spis mieszkańców Krakowa w 1880 r. i Spis mieszkańców Krakowa w 1890 r. Obliczenia własne.

Więcej niż co trzecia (34\%) aktywna zawodowo kobieta mieszkająca w Krakowie w 1869 roku sklasyfikowana została w grupie siódmej, ósmej lub dziewiątej, czyli jako pracownica związana z produkcją i transportem lub robotnica. W kolejnych badanych latach ich udział zmniejszył się do $24 \%$, przy równoczesnym coraz większym znaczeniu grupy piątej (usługi), czwartej (handel) lub zerowej i pierwszej (wolne zawody i inne wysoko wykwalifikowane).

Wśród kobiet pracujących w zawodach zaliczanych do grup 7, 8 i 9 najliczniej reprezentowane były wyrobnice (9-99.20); w 1869 roku stanowily one $41 \%$, w 1880 roku - aż 45\%, a w 1890 roku - jedynie 37\%. Znaczący był też odsetek szwaczek (7-95.20), odpowiednio 30\%,33\% i 23\% oraz krawcowych (7-91.00 i 7-91.40) - 13\%, 10\% i $23 \%$. W sumie kobiety zajmujące się szyciem odzieży (oprócz szwaczek i krawcowych były to także modystki, kapeluszniczki, rękawiczniczki i hafciarki) stanowiły 46\% (w latach 1869 i 1880) i 49\% (w 1890 roku) wszystkich kobiet pracujących w zawodach zaliczanych do grup 7, 8 i 9. Oprócz tego szyciem obuwia zajmowało się 3\% kobiet z grup ,produkcyjnych” w 1869 roku, w latach kolejnych ich udział spadł poniżej 1\%. W 1880 roku 2\%, a w 1890 
roku 5\% kobiet z grup 7, 8 i 9 zajmowało się wytwarzaniem cygar (7-82.00); w 1869 roku nie odnotowano ani jednej, co jednak nie dziwi, gdy weźmiemy pod uwagę fakt, krakowska Cygar-Fabryka została uruchomiona w 1871 roku. Wśród pozostałych krakowianek pracujących w grupach „wytwórczych”, z udziałem poniżej 1\%, odnotowano także: piekarki, pasamoniczki, młynarki, rzeźniczki, drukarki, a nawet panie zajmujące się ciesielstwem.

Pracownice handlu (grupa czwarta) w 1869 roku stanowiły 9\% wszystkich krakowianek aktywnych zawodowo; ich udział w roku kolejnego spisu spadł do ponad $6 \%$, by w 1890 roku ponownie wzrosnąć do $11 \%$.

Sprzedawczynie (4-51.25 i 4-51.30) stanowiły 66\% pracujących w grupie czwartej w 1869 roku, w kolejnych badanych latach odpowiednio 47\% i 56\%. Znaczny był też odsetek straganiarek (4-52.20) - 23\% w 1869 roku, 26\% w 1880 roku i 18\% w 1890 roku. Stosunkowo niewielki - 4\% - był w 1869 roku udział właścicielek sklepów detalicznych (4-10.30) wśród wszystkich pracujących w handlu krakowianek; w latach kolejnych spisów wzrósł znacznie, do 17\% (1880 rok) i 15\% (1890 rok). W 1869 roku nieco ponad 1\% pracujących w grupie czwartej stanowiły kupcowe (4-22.20), taki sam był udział pośredniczek handlowych (4-22.30), w 1880 roku odsetek kupcowych nadal wynosił $1 \%$, natomiast udział pań pośredniczących w handlu wzrósł do blisko 5\%, w 1890 roku kupcowe stanowiły prawie $4 \%$, a pośredniczki - mniej niż $1 \%$ wszystkich krakowianek pracujących w handlu.

Przedstawicielki grup oznaczonych numerami zero i jeden, czyli pracujące $\mathrm{w}$ wolnych zawodach i inne wysoko wykwalifikowane, stanowiły aż $10 \%$ wszystkich aktywnych zawodowo kobiet w Krakowie w 1880 roku. W latach 1869 i 1890 ich udział był o połowę niższy; należy jednak pamiętać, że w tych przypadkach badanie oparte jest na stosunkowo niewielkich liczebnościach, jako że bazy danych dla tych lat zostały zbudowane na podstawie prób statystycznych. W tej sytuacji udziały procentowe mogłyby mieć charakter przypadkowy, dlatego zostaną pominięte.

W latach 1869 i 1890 w grupie 0/1 odnotowano najwięcej nauczycielek i guwernantek, a także akuszerki, pielęgniarki, aktorki i zakonnice. W 1880 roku 59\% wszystkich krakowianek sklasyfikowanych w grupach 0 i 1 stanowiły zakonnice, $30 \%$ - nauczycielki i guwernantki, $7 \%$ - akuszerki, a blisko $2 \%$ - aktorki. Odsetek kobiet pracujących we wszystkich pozostałych zawodach w grupie 0/1 razem nie przekraczał $3 \%$, były wśród nich śpiewaczki i instrumentalistki, kilka pisarek i dziennikarek oraz dwie artystki malarki.

Grupy krakowianek pracujących w zawodach z pozostałych grup głównych HISCO (czyli drugiej - pracownicy administracyjni i zarządzający, trzeciej urzędnicy i tym podobni oraz szóstej - rolnicy, hodowcy, leśnicy, rybacy i myśliwi) były bardzo nieliczne we wszystkich badanych latach. Nawet w 1880 roku, 
w którym poddano analizie 12 tysięcy aktywnych zawodowo kobiet, było w sumie tylko 125 krakowianek pracujących w zawodach zaklasyfikowanych do tych trzech grup głównych. Wśród nich 65 pracowało jako ochmistrzynie (2-24.60), 17 jako kasjerki (3-31.35), a 8 jako telegrafistki (3-80.40). Było też pięć pracownic biurowych (3-93.10) i dwie poczmistrzynie (2-22.20).

\section{Podsumowanie}

W drugiej połowie XIX wieku miała miejsce masowa imigracja do Krakowa. Zmieniała ona strukturę całej populacji, wśród ludności napływającej do miasta znacznie więcej było kobiet niż mężczyzn. Było to związane z miejscowym rynkiem pracy, na którym kobietom było łatwiej znaleźć zatrudnienie, szczególnie niewymagające wysokich kwalifikacji. Dlatego w populacji Krakowa widoczna jest coraz silniejsza feminizacja oraz wyraźna nadreprezentacja „młodych dorosłych" (osób w wieku 15-24 lata).

W badanych latach, w których przeprowadzano spisy powszechne, w populacji miasta wzrastał udział osób aktywnych zawodowo, zarówno wśród mężczyzn, jak i wśród kobiet. Udział kobiet w rynku pracy zwiększał się dużo wyraźniej z $16,5 \%$ do $38,6 \%$.

Pracowały przede wszystkim kobiety stanu wolnego - w 1869 roku panną była co druga krakowianka aktywna zawodowo, w 1890 roku - więcej niż dwie trzecie. Znaczny był także wśród pracujących udział mężatek - w dwóch pierwszych badanych latach wynosił 14\%, w 1890 roku - nawet $17 \%$. Odsetek kobiet zamężnych wśród aktywnych zarobkowo był wprawdzie zdecydowanie mniejszy niż w całej subpopulacji krakowianek, ale absolutnie nie pozwala na stwierdzenie, że zamążpójście oznaczało kres aktywności zawodowej.

Skala aktywności zawodowej krakowianek była zróżnicowana ze względu na wyznawaną religię. Wśród wszystkich mieszkanek Krakowa w drugiej połowie XIX wieku większość stanowiły rzymskie katoliczki, ich udział wzrastał z 57\% w 1869 roku do $70 \%$ w 1890 roku. Wyznawczyniami judaizmu w 1869 roku było $43 \%$ krakowianek, w 1890 roku - już tylko $29 \%$. Na swoje utrzymanie pracowała duża część mieszkających w Krakowie rzymskich katoliczek, w 1869 roku niemal co trzecia (29\%), w 1890 roku - 44\%. Wśród żydówek w 1869 roku pracowała co siódma (14\%), w 1890 roku - więcej niż co czwarta (27\%).

Krakowianki pracowały przede wszystkim w sektorze usługowym, w 1869 roku zawody sklasyfikowane w grupie piątej HISCO (pracownicy usług) wykonywało $41 \%$ aktywnych zawodowo kobiet, w 1880 roku $-58 \%$, w 1890 roku - aż 59\%. 31\% pracujących krakowianek w 1869 roku wykonywało zawód ,produkcyjny" (grupy 7, 8 i 9), ich udział w latach 1880 i 1890 spadł do 24\%. W 1869 roku 
13\% aktywnych zawodowo mieszkanek Krakowa pracowało w handlu (grupa czwarta HISCO), w 1890 roku ich udział był nieco mniejszy - 11\%; była to jedyna grupa zawodów, w której dominowały pracujące kobiety wyznające judaizm, stanowiły one 8\% wszystkich aktywnych zawodowo krakowianek w 1869 roku i 1890 roku, podczas gdy katoliczki odpowiednio 5\% i 3\%. W grupach HISCO: drugiej (pracownicy administracyjni i zarządzający), trzeciej (urzędnicy i tym podobni) i szóstej (rolnicy, hodowcy, leśnicy, rybacy i myśliwi) kobiet niemal nie było; natomiast w grupach $0 / 1$ (wolne zawody i inni wysoko wykwalifikowani) dominowały rzymskie katoliczki, w znakomitej większości zakonnice, ale także nauczycielki i guwernantki, akuszerki i pielęgniarki oraz artystki - aktorki, śpiewaczki, pisarki i dziennikarki.

Tabela 6. Aktywność zawodowa mężczyzn i kobiet współcześnie (w 2012 roku) w polskich miastach i w 1890 roku w Krakowie

\begin{tabular}{lcccccc}
\hline \multirow{2}{*}{ Przedział wieku } & \multicolumn{3}{c}{ W miastach 2012 } & \multicolumn{3}{c}{ Kraków 1890 } \\
\cline { 2 - 6 } & Mężczyźni & Kobiety & Ogółem & Mężczyźni & Kobiety & Ogółem \\
\hline $15-17$ & - & - & 1,1 & 66,2 & 50,9 & 59,0 \\
$18-19$ & 14,6 & 11,0 & 13,1 & 82,6 & 66,3 & 74,0 \\
$20-24$ & 58,3 & 44,7 & 51,7 & 88,7 & 66,2 & 76,0 \\
$25-29$ & 91,4 & 79,6 & 85,6 & 97,2 & 58,1 & 74,5 \\
$30-34$ & 94,9 & 80,7 & 87,9 & 97,6 & 44,4 & 68,0 \\
$35-39$ & 94,4 & 84,9 & 89,7 & 96,5 & 42,3 & 67,5 \\
$40-44$ & 92,0 & 85,3 & 88,7 & 95,7 & 45,5 & 68,3 \\
$45-49$ & 85,7 & 84,0 & 84,7 & 96,5 & 37,5 & 62,5 \\
$50-54$ & 80,1 & 74,1 & 76,8 & 90,9 & 41,7 & 58,9 \\
$55-59$ & 68,5 & 49,1 & 58,0 & 90,3 & 38,9 & 62,7 \\
$60-64$ & 38,1 & 15,6 & 25,6 & 82,1 & 35,4 & 50,9 \\
65 i więcej & 7,3 & 2,7 & 4,5 & 69,7 & 31,4 & 47,1 \\
Wiek nieznany & - & - & - & 95,6 & 40,0 & 85,5 \\
Ogółem & 63,6 & 48,9 & 55,8 & 88,6 & 49,9 & 67,1 \\
\hline
\end{tabular}

Źródło: Rocznik statystyczny pracy 2012, Warszawa 2014, tablica 4: Ludność aktywna zawodowo wedlug wieku w IV kwartale, s. 102; baza danych: Spis mieszkańców Krakowa w 1890 r. Obliczenia własne.

A jeśli chodzi o „mało realną” działalność zawodową kobiet w XIX wieku, to pod koniec stulecia w Krakowie pracowało ich więcej niż współcześnie - mężczyzn zresztą też (tabela 6), powątpiewam zatem, by była ona „źle postrzegana”. Trudno to jednak ocenić na podstawie źródeł o charakterze kwantytatywnym. 


\section{Women's Professional Activity in Cracow of the Second Half of the $19^{\text {th }}$ Century}

\section{Summary}

The article presents the scale of the professional activity of women who lived in Cracow in the second half of the $19^{\text {th }}$ century. The author's intention has been to verify - at least in relation to the urban population - the common belief that before the First World War women did not take up paid jobs to a larger extent.

The analysis contains the Historical International Standard Classification of Occupations (HISCO). The records of censuses of 1869,1880 and 1890 have been the main source for the analysis; thanks to them it was possible to create a database of urban inhabitants.

After having analysed the changes in the size of the population of Cracow in the second half of the $19^{\text {th }}$ century the author attempted to assess what the percentage of the dynamic increase of the Cracow's population might be accounted for by immigrants, identified through their place of birth and citizenship. The incoming population changed the structure of the Cracow's community as far as age and sex are concerned. The majority of the immigrants were young adults, mostly women, and they were looking for a job. In 1869 every sixth woman that lived in Cracow was working; eleven years later - every third, and after another 10 years - nearly $40 \%$ of them. Three quarters of professionally active women from Cracow were Roman Catholic, and only one quarter - Jewish. The article also presents the structure of marital status of working women from Cracow and the type of jobs they had - according to the main groups of HISCO.

It has been proved that the women did not take up jobs motivated by the war crisis; at the end of the $19^{\text {th }}$ century in Cracow there were more working women than in 2012 in Polish towns.

Keywords: Cracow, the second half of the $19^{\text {th }}$ century, women, professional activity, HISCO (Historical International Standard of Classification of Occupations), censuses 